\title{
İran'da Koyun ve Keçilerde Küçükbaş Ruminant Morbillivirusunun (SRMV) Seroprevalansı
}

\section{Seroprevalance of Small Ruminant Morbillivirus (SRMV) in Sheep and Goats in Iran}

Ali Rıza BABAOĞLU1*i, Mohammadreza MAHZOUNIEH² ${ }^{\circledR}$, Seval BILGE DAĞALP3®

Atıf Yapmak İçin: Babaoğlu AR, Mahzounieh M, Dagalp SB. İran'da koyun ve keçilerde küçükbaş ruminant morbillivirusunun (SRMV) seroprevalansı. Van Sag Bil Derg 2021, 14,(1) 86-92. https://doi.org/10.52976/v ansaglik.808712.

Geliş Zamanı: 10/10/2020

Kabul Zamanı: 23/10/2020

Basılama Zamanı: 30/04/2021
1 Van Yüzüncü Yıl Üniversitesi, Veteriner Hekimliği Fakültesi, Viroloji Anabilim Dalı, Van, TÜRKIYYE.

2 Shahrekord Üniversitesi, Veteriner Hekimliği Fakültesi, Patobiyoloji Anabilim Dalı, Shahrekord, IRAN

3 Ankara Üniversitesi, Veteriner Hekimliği Fakültesi, Viroloji Anabilim Dalı, Ankara, TÜRKIYE

* Sorumlu yazar: Ali Rıza BABAOĞLU;E-mail: arbaboglu@yyu.edu.tr.

ÖZET

Amaç: Küçükbaş ruminantların morbillivirusu (SRMV), daha önceki adıyla peste-des-petits ruminants virus (PPRV) enfeksiyonu, küçükbaş ruminantların ekonomik olarak en önemli hastalıklarından biridir. Bu çalışmada, İran'daki küçükbaş ruminantlarda PPRV enfeksiyonunun seroprevalansının belirlenmesi amaçlanmıştır. Materyal ve Metot: İran'ın 9 farklı eyaletindeki (Ardabil, Azarbayjan-e Gharbi, Azarbayjan-e Sharqi, Hormozgan, Esfahan, Fars, Kordestan, Gilan, Shahrekord) işletmelerden elde edilen ve İran/Şehrekord Üniversitesi tanı laboratuvarı stoklarında bulunan kan serumu örnekleri kullanılmıştır. Söz konusu işletmelerde PPRV enfeksiyonuna karşı aşılama yapılmadığı öğrenilmiştir. PPRV, N proteinine karşı gelişen spesifik antikorların tespiti amacıyla, 9 farklı eyaletten elde edilen ve İran/Shahrekord Üniversitesi tanı laboratuvarına getirilen 444 koyun ve 58 keçiden alınan toplam 502 kan serumu örneği C-ELISA kiti (ID Screen® PPRV Competition) ile kontrol edilmiştir.

Bulgular: PPRV seropozitiflik oranı \% 53,38 (268/502) olarak tespit edilmiştir. Örnek alınan eyaletlerden Gilan hariç hepsi PPRV yönünden seropozitif olarak tespit edilmiş ve eyaletlere göre seropozitiflik dağılımının \%12.5 - 96.29 oranları arasında değişim gösterdiği belirlenmiştir. Hayvan türlerine göre seropozitiflik değerlerine bakıldığında ise, örneklenen koyunların \%53.6's1 (238/444) ve keçilerin \%51.7'si (30/58) PPRV spesifik antikorları yönünden pozitif olarak bulunmuştur.

Sonuç: PPRV enfeksiyonunun İran' da endemik olduğu bir kez daha ortaya konmuş; Türkiye'nin sınır komşusu olan İran ve hayvan hareketlerinin sınırlandırılmasının zorluğuna dikkat çekilerek, enfeksiyondan korunmada en etkili yolun duyarlı populasyonun aşılanması üzerinde durulması gerekliliği sonucuna varılmıştır

Anahtar Kelimeler: İran, Keçi, Koyun, PPRV, Seroprevalans.

\section{ABSTRACT}

Objective: Small ruminants morbillivirus (SRMV) infection formerly called peste-des-petits ruminants virus (PPRV) infection is a serious disease of small ruminants as a economically and clinically. The objective of this study was to estimate the seroprevalence of PPRV infection and its related to risk factors in sheep and goats in Iran.

Materails and Methods: Total of 502 blood sera samples collected from goats and sheep in various regions of Iran (Ardabil, Azarbayjan-e Gharbi, Azarbayjan-e Sharqi, Hormozgan, Esfahan, Fars, Kordestan, Gilan, Shahrekord) were tested by Competitive ELISA against PPRV specific antibodies. All of provinces were found to be positive for PPRV antibodies except for Gilan.

Results: The seropositivity rates were determined as $53.38 \%$ (268/502) for tested samples. According to animal species, the value of seroprevalance for PPRV infection were found as 53,6\% (238/444) and 51,7\% (30/58) in sheep and goats, respectively.

Conclusion: PPRV infection once again emphasis to be endemic in the Iran; attention to the difficulty of limiting animal movement, it need to focus on the most effective way about vaccination of susceptible population for prevention of infection and continuous monitoring of infection for economic impact of PPRV in the affected countries.

Keywords: Iran, Goat, Sheep, PPRV, Seroprevalance 


\section{GİRIŞ̧}

Peste des Petits Ruminants Virus (PPRV), koyun ve keçi gibi evcil ruminantların yanı sıra vahşi ruminantlarda da görülen ateş, iştahsızlık, nasal akıntı, hemoraji, ağız mukozasında (dil, dudak, damak) erozyonlar, stomatitis, konjunktivitis, diarrhea ve bronchopneumonie ile karakterize subakut ya da akut viral bir hastalıktır (Diallo 1988; Scott 1990; Kwiatek ve ark., 2007). Özellikle koyun ve keçilerde akut ve oldukça bulaşıcı olan bu viral hastalık, son zamanlarda develerde de ortaya çıktığı görülmektedir (Abubakar ve ark., 2017; Balamurugan ve ark., 2020).

Enfeksiyon Afrika, Arap Yarımadası, Orta Doğu, İç ve Güneydoğu Asya ve Türkiye' de (El hag Ali ve Taylor 1984; Abu Elzein ve ark., 1990; Nanda ve ark., 1996; Ozkul ve ark., 2002; Al-Majali ve ark., 2008; Kwiatek ve ark., 2007; Shabbir ve ark., 2018; Sait ve Bilge-Dağalp, 2019) yaygın olarak görülmektedir. Karantina tedbirlerinin yeterince uygulanmaması ve sinırlarda hayvan hareketlerinin kontrol edilememesi nedeniyle, PPRV enfeksiyonunun kontrol ve eradikasyonu birçok ülkede problem oluşturmaktadir.

Etiyolojik ajan olarak peste-des-petits-ruminant virus (PPRV), son zamanlarda uluslararası virus taksonomi komitesi (ICTV) tarafından küçükbaş ruminant morbillivirus (SRMV) olarak yeniden adland1rılmıştır (Liu ve ark., 2018). Bu virus; Measles Virus (MV), Canine Distemper Virus (CDV) ve Rinderpest Viruslarına (RPV) göre daha sonra morbillivirus genusuna eklenmiştir. PPRV ve RPV, morbillivirus genusuna dahil 5 virus (canine distemper virus, measles virus, dolphin distemper virus, phocine distemper virus ve porpoise distemper virus) ile birlikte Paramyxoviridae ailesinde Morbillivirus genusunda yer almaktadır (McCullough ve ark., 1991; Barrett ve ark., 1993; Govindaraj ve ark., 2016).

Dünya hayvan sağlık örgütü (OIE) tarafından 1994 yılında başlatılan uluslararası sığır vebası (RP) kontrol eradikasyon kampanyası (GREP) dâhilinde yapılan yoğun aşılama çalışmaları, Haziran 2011 yılında hastalığın yeryüzünden eradike edildiğinin bildirilmesi ile son bulmuştur. Ancak, PPRV enfeksiyonu Afrika, Asya, Ortadoğu ve Türkiye'de yayılmaya devam etmekte ve 2030 yılında yeryüzünden eradike edilmesi planlanmaktadır (Schulz ve ark., 2018).

Bu bilgilerden hareketle ve İran' da PPRV enfeksiyonun seroprevalansına ve yaygınlığına ilişkin çalışmaların sınırlı sayıda olması nedeni ile İran'da yetiştirilen küçükbaş ruminantlarda PPRV enfeksiyonunun seroprevalansına ilişkin yeni bilgilerin elde edilmesi amaçlanmıştır.

\section{MATERYAL ve METOT}

\section{Örnekler}

Bu araştırmada, 2009-2012 y1lları arasında İran'ın farklı bölgelerinde bulunan, özellikle Türkiye ve diğer komşularına sınır olan 13 eyaletteki halk işletmelerinde barındırılan 6 ay yaşın üzerindeki koyun ve keçilerden serolojik kontrol amaciyla örnekleme yapıldı. Ayrıca, çalışmada yine aynı zaman aralığında Shahrekord Üniversitesi tanı laboratuvarına PPRV enfeksiyonu şüphesi ile getirilen ancak örnekleme yerlerine ilişkin bilgileri kesin olmayan materyaller de serolojik kontrol amacıyla kullanıldı (Şekil 1). Söz konusu işletmelerde PPRV enfeksiyonuna karşı aşılama yapılmadığı öğrenildi.

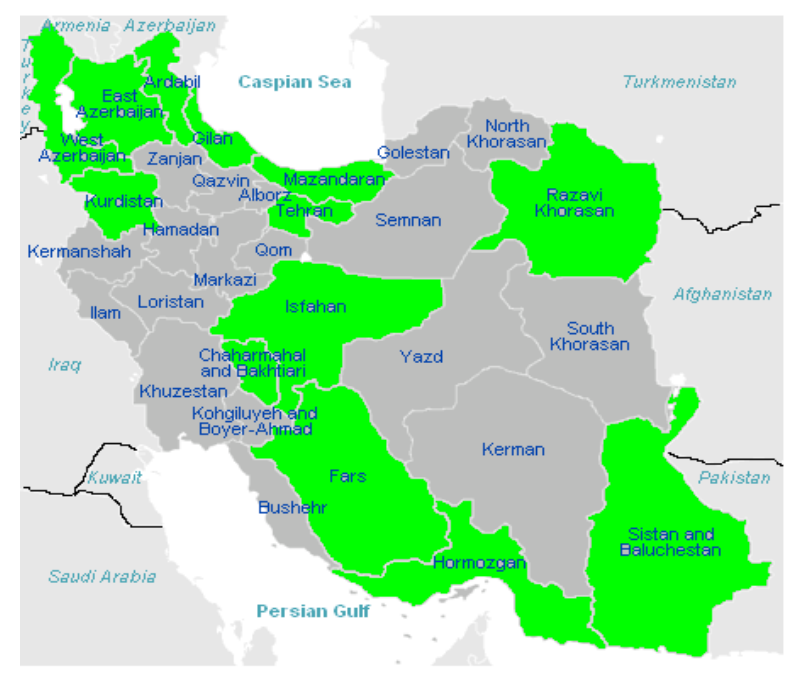

Şekil 1. İran haritası üzerinde örnekleme yapılan eyaletlerin coğrafi konumu (yeşil renk) 


\section{Kan Serum Örneklerinin Hazırlanması}

Serolojik çalışma amacıyla silikonlu tüplere (Venoject, VT-109SAS) alınan toplam 502 kan serum örneği pihtılaştıktan sonra 2000 rpm'de 10 dakika santrifüj (Soğutmalı santrifüj, Sigma, ABD) edilip, serumları ayrıldı; stok tüplerine aktarılan serumlar test edilinceye kadar $-20{ }^{\circ} \mathrm{C}^{\prime}$ de korundu.

\section{PPR C-ELISA}

PPRV N proteinine karşı gelişen spesifik antikorların tespiti amacıyla, 9 farklı ilde bulunan ve Shahrekord Üniversitesi tanı laboratuvarına getirilen 444 koyun ve 58 keçiden alınan toplam 502 kan serum örneği ticari C-ELISA kiti (ID Screen ${ }^{\circledR}$ PPR Competition, ID. VET innovative diagnostics, France) ile test edildi (Tablo 1). C-ELISA tekniği üretici firmanın belirttiği prosedüre uygun olarak gerçekleştirildi.

Kısaca, her bir serum örneği, pozitif ve negatif kontroller tablet gözlerinde sulandırma sıvısı (dilution buffer) ile 1:2 oranında sulandırıld 1 ve $37^{\circ} \mathrm{C}^{\prime}$ de $45 \pm 4$ dakika inkübasyona birakıldı. İnkubasyon sonrasında 1:20 oranında hazırlanmış olan yıkama solüsyonu ile tabletler 3 kere y1kandıktan sonra, 1:10 oranında hazırlanmış olan konjugattan tüm gözlere $100 \mu 1$ ilave edildi ve oda sıcaklığında $30 \pm 3$ dakika inkübasyon birakıldı. İnkubasyon süresi sonunda y1kama işlemi tekrarlandı ve her göze $100 \mu l$ substrat solüsyonu konuldu. Tabletler karanlık bir ortamda, oda 1sısında 15 dakika inkübe edildikten sonra, tüm tablet gözlerine $100 \mu 1$ durdurma solüsyonu konularak reaksiyon sonlandirildi. ELISA tabletleri $450 \mathrm{~nm}$ dalga boyuna sahip filtrenin kullanıldığı ELISA okuyucusunda (Titertek, Finlandiya) değerlendirildi. Elde edilen absorbans değerleri, söz konusu kitin protokolünde belirtilen şekilde değerlendirildi (Tablo 2).
Tablo 1: Koyun ve keçi kan serumu örneklerinin eyaletlere göre dağılımı

* Shahrekord Üniversitesi tanı laboratuvarında bulunan örnekler

\begin{tabular}{|c|c|c|c|}
\hline Sira & Eyalet & Tür & Serum \\
\hline \multirow[t]{2}{*}{1} & \multirow{2}{*}{ Ardabil } & Koyun & 45 \\
\hline & & Keçi & 4 \\
\hline \multirow[t]{2}{*}{2} & Azarbayjan-e & Koyun & 16 \\
\hline & Gharbi & Keçi & --- \\
\hline \multirow[t]{2}{*}{3} & Azarbayjan-e- & Koyun & 120 \\
\hline & Sharqi & Keçi & -- \\
\hline \multirow[t]{2}{*}{4} & \multirow[t]{2}{*}{ Hormozgan } & Koyun & 25 \\
\hline & & Keçi & --- \\
\hline \multirow[t]{2}{*}{5} & \multirow{2}{*}{ Isfahan } & Koyun & 15 \\
\hline & & Keçi & 4 \\
\hline \multirow[t]{2}{*}{6} & \multirow[t]{2}{*}{ Fars } & Koyun & 1 \\
\hline & & Keçi & 10 \\
\hline \multirow[t]{2}{*}{7} & \multirow[t]{2}{*}{ Kordestan } & Koyun & 52 \\
\hline & & Keçi & 8 \\
\hline \multirow[t]{2}{*}{8} & \multirow[t]{2}{*}{ Gilan } & Koyun & 21 \\
\hline & & Keçi & 3 \\
\hline \multirow[t]{2}{*}{9} & \multirow{2}{*}{ Shahrekord } & Koyun & 46 \\
\hline & & Keçi & 8 \\
\hline & \multirow{2}{*}{ Tanı Lab.* } & Koyun & 103 \\
\hline-- & & Keçi & 21 \\
\hline \multirow{2}{*}{\multicolumn{2}{|c|}{ Genel Toplam }} & Koyun: 444 & \\
\hline & & Keçi: 58 & \\
\hline
\end{tabular}

Tablo 2. PPRV-ELISA değerlendirme tablosu

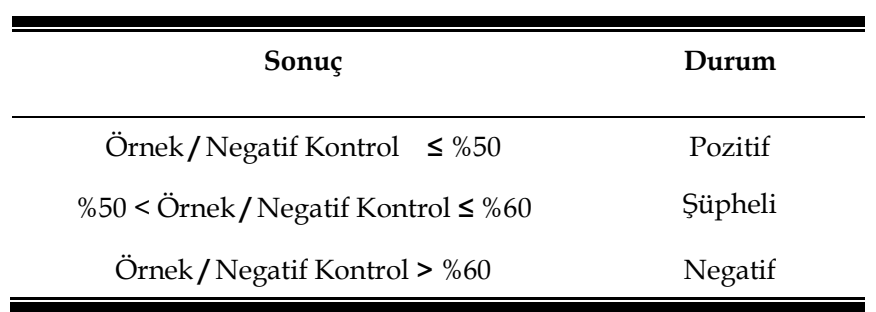




\section{BULGULAR}

PPRV spesifik antikor tespiti amaciyla yapılan CELISA sonucunda, PPRV enfeksiyonu için seropozitiflik oranı koyunlarda \%53.60 (238/444), keçilerde ise $\% 51.70(30 / 58)$ olarak belirlendi. Çalışmaya dahil edilen tüm hayvanlar göz önüne alındığında seropozitiflik oranı \% 53,38 (268/502) olarak tespit edildi. Örnek alınan eyaletlerden Gilan eyaleti hariç hepsi PPRV antikorları yönünden pozitif olarak değerlendirilmiş ve eyaletlere göre seropozitiflik oranları dağılımının \%12.5 - 96.29 oranları arasında değişim gösterdiği belirlenmiştir (Tablo 3).

Tablo 3. Eyaletlere göre PPRV enfeksiyonunun dağılımı

\begin{tabular}{|c|c|c|c|c|}
\hline \multirow{2}{*}{ İL Adı } & \multirow{2}{*}{ Tür } & \multirow{2}{*}{ Serum } & \multicolumn{2}{|c|}{ C-ELISA } \\
\hline & & & Pozitif & Prevalans(\%) \\
\hline \multirow{2}{*}{ Ardabil } & Koyun & 45 & 5 & 11,11 \\
\hline & Keçi & 4 & 4 & 100 \\
\hline \multirow{2}{*}{ Azarbayjan-e Gharbi } & Koyun & 16 & 2 & 12,5 \\
\hline & Keçi & 0 & 0 & -- \\
\hline \multirow{2}{*}{ Azarbayjan-e-Sharqi } & Koyun & 120 & 94 & 78,33 \\
\hline & Keçi & 0 & 0 & -- \\
\hline \multirow{2}{*}{ Hormozgan } & Koyun & 25 & 19 & 76 \\
\hline & Keçi & 0 & 0 & -- \\
\hline \multirow{2}{*}{ Esfahan } & Koyun & 15 & 13 & 68,42 \\
\hline & Keçi & 4 & 0 & 0 \\
\hline \multirow{2}{*}{ Fars } & Koyun & 1 & 1 & 100 \\
\hline & Keçi & 10 & 9 & 90 \\
\hline \multirow{2}{*}{ Kordestan } & Koyun & 52 & 41 & 78,84 \\
\hline & Keçi & 8 & 7 & 8,75 \\
\hline \multirow{2}{*}{ Gilan } & Koyun & 21 & 0 & 0 \\
\hline & Keçi & 3 & 0 & 0 \\
\hline \multirow{2}{*}{ Shahrekord } & Koyun & 46 & 46 & 100 \\
\hline & Keçi & 8 & 6 & 75 \\
\hline \multirow{2}{*}{ Tanı Lab. } & Koyun & 103 & 17 & 16,5 \\
\hline & Keçi & 21 & 4 & 19,04 \\
\hline \multirow{2}{*}{ Tür Toplam } & Koyun & 444 & 238 & 53,60 \\
\hline & Keçi & 58 & 30 & 51,7 \\
\hline Genel Toplam & Koyun+Keçi & 502 & 268 & 53,38 \\
\hline
\end{tabular}

\section{TARTIŞMA}

Uzun yıllar PPR enfeksiyonunun Afrika'ya özgü bir hastalık olduğu ve Batı ile İç Afrika'da lokalize olduğu düşünülmüştür (Losos,1994). Çok daha sonraları enfeksiyonun Afrika'nın dışında Yakın ve Orta Doğu, Arap Yarımadası, Türkiye, İran, Irak, Pakistan,
Hindistan, Bangladeş, ve Kazakistan'da da endemik olduğu anlaşılmıştır (Taylor ve ark., 2002). Etkili ve zayıflatılmış bir canlı aşısı olmasına rağmen son yıllarda virus, Batıda Fas'tan, Doğuda Çin ve Moğolistan'a kadar yayılmaya devam etmektedir (Baron ve ark., 2017). 
PPRV enfeksiyonunun İran' da 1995 yılında ilk tespitinin ardından, ülke geneline yayılan enfeksiyon büyük ekonomik kayıplara neden olmuştur (Bazargani ve ark., 2006). Daha sonraki yıllarda, duyarlı hayvanların RPV aşısı ile aşılanması ve bazı kontrol tedbirlerine rağmen oranları değişmekle birlikte İran' in farklı eyaletlerinde PPR enfeksiyonunun varlığ1 tespit edilmiştir (Abdoullahpour ve ark., 2006; Bazargani ve ark., 2006; Hemmatzadeh ve ark., 2016). Ancak İran' da PPRV enfeksiyonunun seroprevalansına ve yaygınlığına ilişkin çalışmalar sınırlı sayıdadir.

Bu çalışmada, toplam 502 kan serum örneği PPRV spesifik antikorların belirlemek üzere C-ELISA ile kontrol edilmiş ve seropozitiflik oranı \% 53,38 (268/502) olarak tespit edilmiştir. Örnek alınan eyaletlerden Gilan eyaleti hariç hepsi PPRV yönünden seropozitif olarak tespit edilmiş ve seropozitiflik oranlarının eyaletlere göre \%12.5-96.29 arasında değişim gösterdiği belirlenmiştir. Hayvan türlerine göre seropozitiflik değerlerine bakıldığında ise, örneklenen koyunların \%53.6 si (238/444), keçilerin \%51.7 si (30/58) PPRV antikorları yönünden pozitif olarak bulunmuştur. Daha önceki çalışmada Hessami ve ark. (1994) İran'da klinik olarak semptom göstermeyen koyun ve keçi kan serumlarında PPRV enfeksiyonuna karş1 \%13 oranında seropozitiflik saptamışlardır. Hemmatzadeh ve ark. (2016) örnekleme yapılan 64 serbest dolaşan yaban küçük ruminantında seropozitiflik oranını \%17 olarak ortaya koymuşlar. Başka bir çalışmada İran'ın Güneyinde bulunan Fars eyaletinde 4 farklı PPRV salg1nında sandiviç-ELISA yöntemi ile şüpheli örneklerde \%100 seropozitiflik tespit edilmiştir (Shahriari ve ark. 2019).

İran' ın komşu ülkelerinden olan Türkiye' de Tatar ve Alkan (1998) tarafından PPRV enfeksiyonunun Türkiye'deki seroepidemiyolojik durumuyla ilgili olarak yapılan ilk çalışmada, toplam 206 kan serum örneğinde C-ELISA ile seropozitiflik oranı koyun serumlarında $\% 87,95$, keçi serumlarında ise $\% 90$ olarak tespit edilmiştir. Özkul ve ark. (2002) tarafından ya- pılan bir diğer çalışmada, 18 farklı bölgeden sağlanan 1077 koyun kan serumunda C-ELISA tekniği ile seropozitiflik oranı \%29.2 olarak belirtilmiştir. Albayrak ve Alkan (2009) Türkiye' de Orta ve Doğu Karadeniz bölgesine ait 892 koyundan sağlanan kan serum örneklerinde seropozitiflik oranını \%14.9 olarak bildirmişlerdir. Başka bir çalışmada Türkiye' de 2010 yılında 82 ceylana ait kan serumu örneğinde PPRV'ye karşı antikor pozitiflik oranını \%12 olarak bildirilmiştir (Gür ve Albayrak, 2010).

Pakistan'da yapılan bir çalışmada (Aslam ve ark., 2009) 3 farklı bölgeden alınan 160 keçi ve koyun (60/100) kan serumunda, C-ELISA ile \%31.25 oranında seropozitiflik saptanmıştır. Yine Pakistan'da 27 ili kapsayan rastgele örnekleme yapılan başka bir çalışmada, alınan 2798 koyun ve keçi kan serumu örneklerinde C-ELISA ile \%45.5 oranında seropozitiflik bildirilmiştir (Zahur ve ark., 2011). Son zamanlarda Pakistan'da PPR enfeksiyonuna yönelik salgın dalgalarının varlığı moleküler yöntemler ile de ortaya konmuştur (Shabbir ve ark., 2018).

İran'ın iki komşu ülkesi olan Pakistan ve Türkiye' de elde edilen seropozitiflik oranları ile bu çalışmada örneklenen populasyon için saptanan seropozitiflik oranları karşılaştırıldığında, İran'da seropozitiflik değerleri benzer oranlarda bulunmuştur. Bilindiği üzere seroprevalans çalışmalarının sonuçları ülkedeki hayvan sayısı ve buna bağlı olarak örneklenen hayvan sayısı, hayvanların yaşı, örnekleme zamanı, hayvan ırkları, bakım ve besleme koşulları, vb. birçok faktörden etkilenmektedir. Dolayısıyla İran'da ve komşu ülkelerdeki çalışmalar ile ilgili sonuçlar genel olarak değerlendirildiğinde, enfeksiyonun İran'da endemik olarak varlığ konmuş ve etkili kontrol tedbirlerinin alınmamasının sonucu olarak giderek yaygınlığının arttığı görülmüştür.

$\mathrm{Bu}$ araştırmada, enfeksiyonun seroprevalansına bağlı olarak enfeksiyonun varlığının ve yaygınlığının belirlenmesinin yanı sıra, enfeksiyonun seroepidemiyolojisine ilişkin güncel verilere ulaşmamız da 
sağlanmıştır. Bu bağlamda, koyun ve keçi sürülerinde PPRV yönünden serolojik olarak sporadik ve saha taraması, enfeksiyonun kontrolünde oldukça önemlidir. Seroepidemiyolojik veriler sayesinde hastalığın kontrolüne yönelik alınacak aşılama ve karantina gibi tedbirlerin hızlı bir şekilde uygulanması da enfeksiyonun kontrolünde ekili olacaktır. Böylece salgınların neden olduğu ciddi ekonomik kayıpların önüne geçilebileceği de düşünülmektedir. Ayrıca, PPRV enfeksiyonunun kontrolü ve eradikasyonu amacıyla evcil hayvanlarda enfeksiyonun varlığının araştırılmasının yanı sıra, yabani hayvan popülasyonlarındaki varlığı da enfeksiyonun epidemiyolojisine etki eden önemli bir faktör olarak araştırılmaya ihtiyaç duymaktadır.

\section{Teşekkürler}

Bu çalışma, birinci isim yazarın "İran' da Koyun ve Keçilerde PPRV Enfeksiyonunun Epidemiyolojisi" başlıklı doktora tezinin bir kısmından özetlenmiştir. Çalışma süresince Ankara Üniversitesi, Veteriner Fakültesi, Viroloji Anabilim Dalının olanaklarından faydalanmamı sağlayan tüm öğretim üyelerine teşekkür ederiz

\section{Çıkar Çatışması}

Yazarlar çıkar çatışması olmadığını beyan eder.

\section{KAYNAKLAR}

Abdollahpour G, Raoofi A, Najafi J, Sasai F, Sakhaie E. clinical and para-clinical findings of a recent outbreaks of Peste des Petits ruminants in Iran. J Vet Med 2006; B 53: 14-6.

Abubakar M, Mahapatra M, Muniraju M, Arshed M.J, Khan EH, Banyard AC et al. Serological detection of antibodies to Peste des Petits ruminantsvirus in large ruminants. Transbound Emerg Dis 2017;64 (2): 513-9.

Abu Elzein EME, Hassanien MM, Al-Afaleq AI, Abd Elhadi MA, Housawi FMT. Isolation of peste des petitts ruminants from goats in Saudi Arabia. Vet Record 1990;127: 309-10.
Albayrak H, Alkan F. PPR virus infection on sheep in Blacksea region of Turkey: epidemiology and diagnosis by RT-PCR and virus isolation. Vet Res Commun 2009; 33(3):241-9.

Al-Majali A, Hussain N, Amarin N, Majok A. Seroprevalence of, and risk factors for, Peste des Petits ruminants in sheep and goats in Northern Jordan. Prev Vet Med 2008;85(1-2):1- 8 .

Aslam M, Abubakar M, Anjum1 R, Saleha S, Ali Q. Prevalence of Peste des Petits ruminants virus (PPRV) in Mardan, Hangu and Kohat District of Pakistan; comparative analysis of PPRV suspected serum samples using competitive ELISA (cELISA) and agar gel immunodiffusion (AGID). Vet World 2009;2(3): 89-92.

Balamurugan V, Varghese B, Muthuchelvan D, Sowjanya Kumari S, Vinod Kumar K, Dheeraj R et al.. Seroprevalence of Peste des Petits ruminants in small ruminants in the North Eastern Region of India. Vet Italian 2020;56(1):55-60.

Baron MD, Diop B, Njeumi F, Willett BJ, Bailey D. Future research to underpin successful Peste des Petits ruminants virus (PPRV) eradication. J Gen Virol 2017;98(11):2635-44.

Bazarghani T, Charkhkar S, Doroudi J, Bani Hassan E. A Review on Peste des Petits ruminants (PPR) with special reference to PPR in Iran J Vet Med 2006;B 53:17-8.

Barrett T, Visser IKG, Mamaev L, Goatley L, Bressem MF, Van Osterhaus ADM. Dolphine and porpoise morbilliviruses are genetically distinct from phocine distemper virus. Virology 2006;193: 1010-2.

Diallo, A. Rinderpest and Peste des Petits ruminants; constant threats to animal farming in many developing countries. Impact Sci Soc 1988;150:17992.

El Hag Al B, Taylor WP. Isolation of Peste des Petits ruminants virus from the Sudan. Res Vet Sci 1984;36:1-4. 
Govindaraj GN, Balamurugan V, Rahman H. Estimation of economic Loss of PPR in sheep and goats in India: an annual incidence based analysis. $\mathrm{Br}$ J Virol 2016;3:77-85.

Gür S, and Albayrak H. Seroprevalance of Peste des Petits ruminants (PPR) in goitered gazelle ( $\mathrm{G} a-$ zella subgutturosa subgutturosa) in Turkey. J Wildlife Dis 2010;46(2): 673-7.

Hemmatzadeh F, Boardman W, Alinejad A, Hematzade A, Kharazian Moghadam M. Molecular and serological survey of selected viruses in free-ranging wild ruminants in Iran. Plos One 2016;11(12):e0168756.

Hessami M, Moakhar R.K, Khedmatı K, Sarmest R. Seroepidemiology of rinderpest and Peste des Petits ruminants in sheep and goats in Iran. Arch Inst Razi 1994; 44-45:19-23.

Kwiatek O, Minet C, Grillet C, Hurard C, Carlsson E, Karimov B et al. Peste des petits ruminants (PPR) outbreak in Tajikistan. J Comp Path 2007;136:111-9.

Liu F, Li J, Li L, Liu Y, Wu X, Wang Z. Peste des petits ruminants in China since its first outbreak in 2007: A 10-year review. Transbound Emerg Dis 2018; 65 (3):638-48.

Losos G.J. Peste des petits ruminats. In.: Infectious Tropical Diseases of Domestic Animals. 1994; The Bath Pres. p.: 549-558.

McCullough SJ, McNeilly F, Allan GM, Kennedy S, Smyth JA, Cosby SL et al. Isolation and characterisation of a porpoise morbillivirus. Arch Virol 1991;118:247-52.

Nanda YP, Chatterjce A, Purohit AK, Diallo A, Inui $\mathrm{K}$, Sharma RN et al. The isolation of Peste des Petits ruminants virus from Nothern India. Vet Microbiol 1996; 51: 207-16.

Ozkul A, Akca Y, Alkan, F, Barrett T, Karaoglu T, Dagalp SB et al. Prevalance, distribution and host range of Peste des Petits ruminants virus, Turkey. Emerg Infect Dis 2002;8 (7) : 08-12.
Sait A, Bilge Dagalp S. Molecular analysis of Peste des Petits ruminants virus from outbreak in Turkey during 2010-2012. J Hellenic Vet Med Soc 2019;70(3):1637-44.

Schulz C, Fast C, Schlottau K, Hoffmann B, Beer M. Neglected hosts of small ruminant morbillivirus. Emerg Infect Dis 2018;24(12):2334-7.

Scott GR. Rinderpest and Peste des Petits ruminants (Goat plaque). In: Virus Infections of Ruminants.1990; Edd: Z. Dinter, B. Morein, Elsevier Science Publisher, chapter.32-33 p.:341-361.

Shabbir MZ, Ul-Rahman A, Zahid MN, Munir M. Genetic characterization of small ruminant morbillivirus from recently emerging wave of outbreaks in Pakistan. Transbound Emerg Dis 2018; 65(6):2032-8.

Shahriari R, Khodakaram-Tafti A, Mohammadi A. Molecular characterization of Peste des Petits ruminants virus isolated from four outbreaks occurred in Southern Iran. BMC Vet Res 2019;15:177.

Tatar N, Alkan F. Koyun ve keçilerde küçük ruminantların vebası (PPR) ve sığır vebası enfeksiyonlarının serolojik ve virolojik olarak araştırılması. 1998; Ankara Üniversitesi, Sağlık Bilimleri Enstitüsü, Doktora tezi.

Taylor WP, Diallo A, Gopalakrishna S, Sreeramalu P, Wilsmore AJ, Nanda YP et al. Peste des petits ruminants has been widely present in southern India since, if not before, the late 1980s. Prev Vet Med 2002;52: 305-12.

Zahur AB, Ullah A, Hussan, M, Irshad H, Hameed A, Jahangir M et al. Sero-epidemiology of Peste des Petits ruminants (PPR) in Pakistan. Prev Vet Med 2011;102:87- 92. 